\title{
Evaluation of constitutive iron reductase (AtFRO2) expression on mineral accumulation and distribution in soybean (Glycine max. L)
}

\author{
Marta W. Vasconcelos ${ }^{1,2}{ }^{*}$, Thomas E. Clemente ${ }^{3}$ and Michael A. Grusak ${ }^{2}$ \\ ${ }^{1}$ Centro de Biotecnologia e Química Fina, Escola Superior de Biotecnologia, Centro Regional do Porto da Universidade Católica Portuguesa, Porto, Portugal \\ ${ }^{2}$ Department of Pediatrics, USDA-ARS Children's Nutrition Research Center, Baylor College of Medicine, Houston, TX, USA \\ ${ }^{3}$ Center for Biotechnology - Plant Science Initiative, University of Nebraska-Lincoln, Lincoln, NE, USA
}

\section{Edited by:}

Paloma Koprovski Menguer, John Innes Centre, UK

\section{Reviewed by:}

Sebastien Thomine, Centre National de la Recherche Scientifique, France Graziano Zocchi, Università degli Studi di Milano, Italy

\section{*Correspondence:}

Marta W. Vasconcelos, Centro de Biotecnologia e Química Fina, Escola Superior de Biotecnologia, Centro Regional do Porto da Universidade Católica Portuguesa, Rua Dr. António Bernardino de Almeida, 4200-072 Porto, Portugal

e-mail:mvasconcelos@porto.ucp.pt

\section{${ }^{\dagger}$ Present address}

Marta W. Vasconcelos, Laboratório Associado, Centro de Biotecnologia e Química Fina, Escola Superior de Biotecnologia, Universidade Católica do Porto, Rua Dr. António Bernardino de Almeida, 4200-072 Porto, Portugal
Iron is an important micronutrient in human and plant nutrition. Adequate iron nutrition during crop production is central for assuring appropriate iron concentrations in the harvestable organs, for human food or animal feed. The whole-plant movement of iron involves several processes, including the reduction of ferric to ferrous iron at several locations throughout the plant, prior to transmembrane trafficking of ferrous iron. In this study, soybean plants that constitutively expressed the AtFRO2 iron reductase gene were analyzed for leaf iron reductase activity, as well as the effect of this transgene's expression on root, leaf, pod wall, and seed mineral concentrations. High Fe supply, in combination with the constitutive expression of AtFRO2, resulted in significantly higher concentrations of different minerals in roots ( $\mathrm{K}, \mathrm{P}, \mathrm{Zn}, \mathrm{Ca}, \mathrm{Ni}, \mathrm{Mg}$, and $\mathrm{Mo}$ ), pod walls ( $\mathrm{Fe}, \mathrm{K}, \mathrm{P}, \mathrm{Cu}$, and $\mathrm{Ni})$, leaves ( $\mathrm{Fe}, \mathrm{P}, \mathrm{Cu}, \mathrm{Ca}, \mathrm{Ni}$, and $\mathrm{Mg}$ ) and seeds ( $\mathrm{Fe}, \mathrm{Zn}, \mathrm{Cu}$, and $\mathrm{Ni})$. Leaf and pod wall iron concentrations increased as much as $500 \%$ in transgenic plants, while seed iron concentrations only increased by $10 \%$, suggesting that factors other than leaf and pod wall reductase activity were limiting the translocation of iron to seeds. Protoplasts isolated from transgenic leaves had three-fold higher reductase activity than controls. Expression levels of the iron storage protein, ferritin, were higher in the transgenic leaves than in wildtype, suggesting that the excess iron may be stored as ferritin in the leaves and therefore unavailable for phloem loading and delivery to the seeds. Also, citrate and malate levels in the roots and leaves of transgenic plants were significantly higher than in wild-type, suggesting that organic acid production could be related to the increased accumulation of minerals in roots, leaves, and pod walls, but not in the seeds. All together, these results suggest a more ubiquitous role for the iron reductase in whole-plant mineral accumulation and distribution.

Keywords: FRO2, iron, mineral nutrition, soybean, transgenic

\section{INTRODUCTION}

Iron is one of the most important micronutrients in human and plant nutrition, and a suitable level of iron nutrition in plants is vital to providing adequate concentrations of this mineral in the harvestable plant organs for human food or animal feed. Researchers have been interested in creating plant foods that are nutrient-dense (to guarantee "nutrient security") in iron and other minerals (Carvalho and Vasconcelos, 2013), using an approach referred to as biofortification. Soybean, being an important plant food in several parts of the world, would be a suitable target for biofortification programs. However, in soybean, most biofortification strategies have aimed at increasing sulfur amino acids (Dinkins et al., 2001) and vitamins, such as $\alpha$-tocopherol (Dwiyanti et al., 2011), and not at increasing mineral concentrations.

To create crop plants with more minerals, researchers must boost their mobilization and uptake from the soil, improve their movement to the edible portions of the plant and ultimately, enhance their storage in those tissues. For this, it is essential to understand the relevant contributions of the mineral transport system throughout the plant as well as the regulatory system that controls it.

One possible strategy is to utilize a "bottom up" approach, where scientists enhance the mechanism of iron uptake from the roots, and "hope" that the additional iron will be mobilized and stored in the edible parts of the plant. Mineral elements traverse the root via apoplastic and/or symplastic pathways to the stele, where they are loaded into the xylem for transport to the shoot (White and Broadley, 2009). In the plant kingdom there are two main strategies for iron uptake. Dicots, such as soybean, and non-graminaceous monocots, respond to iron limiting environments by induction of the Strategy I mechanism (Römheld and Marschner, 1986; Marschner, 1995), which involves several processes at the root membrane such as the expression of active proton pumps (AHA2) to increase solubility of ferric $\left(\mathrm{Fe}^{+3}\right)$ iron, a ferric reductase $(\mathrm{FRO} 2)$ to generate ferrous $\left(\mathrm{Fe}^{+2}\right)$ iron, and an iron transporter (IRT1) to take up this reduced, available iron 
from the rhizosphere (Hell and Stephan, 2003). This uptake system depends on the activity of specific transcription factors, such as FIT and bHLH proteins. Recent work in Arabidopsis and Medicago has shown that Strategy I plants also produce species-specific iron deficiency-elicited compounds, namely phenolics and flavins (Rodríguez-Celma et al., 2013) such as scopoletins (Fourcroy et al., 2013). Monocots utilize the Strategy II mechanism, in which there is extrusion of phytosiderophores that chelate iron and then are taken up as an iron-chelate complex by root specific transporters. Several comprehensive reviews are currently available on this topic (Curie and Briat, 2003; Walker and Waters, 2011; Hindt and Guerinot, 2012; Ivanov et al., 2012; Kobayashi and Nishizawa, 2012).

The Arabidopsis FRO2 gene is a member of the FRO gene family and encodes an iron-deficiency inducible iron reductase responsible for reducing iron at the root surface (Yi and Guerinot, 1996; Robinson et al., 1999; Connolly et al., 2003). Once inside the roots, iron is transported via the xylem to the vegetative tissues in response to transpirational activity from various organs. It is thought that iron is transported in the xylem as a complex with organic acids (OA) such as citrate (Tiffin, 1966; RellánÁlvarez et al., 2010), and that nicotianamine (NA) also may play an important role in this process (Curie et al., 2009; Ivanov et al., 2012).

The role of iron reduction in the roots is well documented (Robinson etal., 1999; Connolly etal., 2003; Mukherjee et al., 2006); however, the role of the reductase in the leaf, fruit, and grain is still unclear. It is thought that iron reduction is necessary to reduce ferric iron in the aerial parts of the plant before being transported into the leaf cells (Larbi et al., 2001; Feng et al., 2006). It was found that AtFRO7 localizes to the chloroplast and is required for efficient photosynthesis in young seedlings and for survival under iron-limiting conditions (Jeong et al., 2008). Iron reductase activity has been detected in leaves of different plant species such as sunflower (de la Guardia and Alcántara, 1996), Vigna unguiculata (Brüggemann et al., 1993) and sugar beet (Gonzalez-Vallejo et al., 2000; Larbi et al., 2001).

Once in the leaves, iron is used in diverse biochemical processes, or it can be stored for future use. The storage form of iron and the organelles where it is accumulated is only partially defined. It is thought that most of the iron will be stored as ferritin in the plastids (chloroplasts contain up to $90 \%$ of the leaf cell iron), with about half in the stroma and half in the thylakoid membranes. The remaining iron pool will probably be found in the vacuole (Thomine et al., 2003). There also seems to be a role for the reductase in the transport to and eventual accumulation of iron in seeds (Grusak, 1995). A pea mutant ( $d g l)$ was identified that has uncontrolled hyperaccumulation of $\mathrm{Fe}$ in vegetative tissues, and that has the ability to accumulate up to 3-fold higher concentrations of $\mathrm{Fe}$ in the seeds (Marentes and Grusak, 1998). Another pea mutant, brz (bronze leaves) also has been shown to have hyperaccumulation of iron in the leaves, but it does not move excess iron into the seeds (Grusak, 1995). Unfortunately, there are no data on the possible role of leaf iron reduction in the transport of iron to the developing seeds.

There is also very limited information on the common regulatory mechanisms that co-regulate the uptake, transport and accumulation of iron and other minerals in the plant. Several common transporters have been identified, but only limited evidence is available on the effects of higher Fe intake on the dynamics of other minerals, such as zinc $(\mathrm{Zn})$, copper $(\mathrm{Cu})$, manganese $(\mathrm{Mn})$, magnesium $(\mathrm{Mg})$, phosphorous $(\mathrm{P})$, potassium $(\mathrm{K})$, nickel (Ni), molybdenum (Mo), or calcium (Ca). All of these also play important roles in human and animal nutrition, and enhanced accumulation of more than one mineral could be a cost effective strategy in biofortification programs.

Ectopic expression of the Arabidopsis thaliana ferric chelate reductase, AtFRO2 (Robinson et al., 1999) in transgenic soybean conferred increased iron reduction in the roots and enhanced tolerance towards iron deficiency chlorosis (Vasconcelos et al., 2006). To determine if the reductase activity is a rate-limiting step for seed mineral acquisition, and to establish AtFRO2 as a possible molecular tool to be used in biofortification programs, we functionally analyzed the transgenic soybean line 392-3 carrying the Arabidopsis FRO2 gene under the 35S constitutive promoter for leaf iron reductase activity and general whole-plant mineral distribution.

\section{MATERIALS AND METHODS PLANT MATERIAL}

Soybean (Glycine max L.) genotypes "Thorne" wild-type (WT) and transgenic homozygous line 392-3 carrying the FRO2 gene from Arabidopsis thaliana under the constitutive $35 \mathrm{~S}$ promoter (Vasconcelos et al., 2006) were used in this study. Plants were grown in a controlled environment chamber with $16-\mathrm{h}, 20^{\circ} \mathrm{C}$ day and 8 -h, $15^{\circ} \mathrm{C}$-night. Relative humidity was maintained at $50 \%$ and photon flux density during the day was $350 \mu \mathrm{mol} \mathrm{m}^{-2}$ $\mathrm{s}^{-1}$, supplied by a mixture of incandescent bulbs and fluorescent lamps. Seeds of control and homozygous transgenic plants in $\mathrm{T}_{3}$ generation were first germinated in beakers with wet filter paper for 4 days before being transferred to hydroponics solution (four plants per $4.5 \mathrm{l}$ ) with different Fe treatments. The standard solution for hydroponically grown plants contained: $0.8 \mathrm{mM} \mathrm{Ca}\left(\mathrm{NO}_{3}\right)_{2}, 1.2 \mathrm{mM} \mathrm{KNO}_{3}, 0.2 \mathrm{mM} \mathrm{MgSO}_{4}, 0.3 \mathrm{mM}$ $\mathrm{NH}_{4} \mathrm{H}_{2} \mathrm{PO}_{4}, 25 \mu \mathrm{M} \mathrm{CaCl}, 25 \mu \mathrm{M} \mathrm{H} \mathrm{H}_{3}, 0.5 \mu \mathrm{M} \mathrm{MnSO}$, $2.0 \mu \mathrm{M} \mathrm{ZnSO}_{4}, 0.5 \mu \mathrm{M} \mathrm{CuSO}_{4}, 0.5 \mu \mathrm{M} \mathrm{H}_{2} \mathrm{MoO}_{4}$, and $0.1 \mu \mathrm{M}$ $\mathrm{NiSO}_{4}$. For various studies, plants were grown either at 0,10 , 32, or $100 \mu \mathrm{M}$ Fe(III)-EDDHA [ethylenediamine-N,N'bis(ohydroxyphenyl)acetic acid]. All nutrients were buffered with $1 \mathrm{mM}$ MES (2,4-morpholino-ethane sulfonic acid), pH 5.5 and growth solutions were changed weekly until full maturity (FM) of the plants.

For mineral analysis, tissues were collected at three developmental stages: 40 (Grain-Fill I), 80 (Grain-Fill II), and 120 (Grain-Fill III) days after the initiation of flowering.

\section{LEAF PROTOPLAST ISOLATION AND REDUCTION ACTIVITY}

Trifoliate leaves of Thorne and 392-3 were collected at two weeks of age from plants grown with $0,10,32$, or $100 \mu \mathrm{M}$ Fe(III)-EDDHA. Protoplasts were isolated using a method modified from Larbi et al. (2001). Specifically, leaf tissue of a known surface area was cut and placed in Solution A (500 mM D-sorbitol, $1 \mathrm{mM} \mathrm{CaCl}_{2}, 2 \%$ [w/v] cellulase, $0.3 \%$ macerozyme, $0.1 \%$ pectolyase, $5 \mathrm{mM} \mathrm{MES,} \mathrm{pH} \mathrm{5.5).}$ The macerate was incubated at $27^{\circ} \mathrm{C}$ for $3 \mathrm{~h}$ on an orbital shaker at 
$70 \mathrm{rpm}$, in the dark. Protoplasts were filtered, centrifuged, washed with Solution B $\left(500 \mathrm{mM}\right.$ D-sorbitol, $1 \mathrm{mM} \mathrm{CaCl}_{2}$ and $5 \mathrm{mM}$ MES, $\mathrm{pH}$ 6.0), isolated after sucrose layering and centrifugation, sized, and counted for viability. Protoplasts were sized by using a calibrated eyepiece fitted to a microscope (Nikon, Japan, $40 \times$ objective). The number of protoplasts per unit volume was determined with a hemacytometer (Hausser Scientific, Horsham, PA, USA), and viability of the protoplasts was calculated by incubation of the protoplast suspension in $0.04 \%$ (w/v) Evans Blue for $5 \mathrm{~min}$, and determining the number of protoplasts excluding the dye. A $500 \mu \mathrm{l}$ volume of leaf protoplast solution was added to $500 \mu \mathrm{l}$ of Solution B (described above) supplemented with $800 \mu \mathrm{M}$ BPDS and $800 \mu \mathrm{M} \mathrm{Fe}(\mathrm{III})$-EDTA. Tubes were agitated for $45 \mathrm{~min}$ at $27^{\circ} \mathrm{C}$, centrifuged $(2 \mathrm{~min}$ at $12,000 \mathrm{~g}$ ) and absorbances read at $535 \mathrm{~nm}$. The extinction coefficient of $\mathrm{Fe}(\mathrm{II})-\mathrm{BPDS}_{3}\left(22.14 \mathrm{mM}^{-1} \mathrm{~cm}^{-1}\right)$ was used to calculate the Fe reduction rates; values are presented on protoplast surface area basis (nmol of Fe reduced $\mu \mathrm{m}^{-2} \mathrm{~s}^{-1}$ ).

\section{TISSUE ELEMENTAL ANALYSIS}

All tissues were harvested and dried overnight in a $60^{\circ} \mathrm{C}$ oven. Samples were then digested overnight in borosilicate glass tubes by adding $4 \mathrm{ml}$ of redistilled $98.8 \% \mathrm{HNO}_{3}$ and $1 \mathrm{ml}$ of concentrated trace metal grade $\mathrm{HClO}_{4}$. Samples were heated at $100^{\circ} \mathrm{C}$ for $1 \mathrm{~h}$, $150^{\circ} \mathrm{C}$ for $1 \mathrm{~h}, 180^{\circ} \mathrm{C}$ for $1 \frac{1}{2} \mathrm{~h}$ and then at $210^{\circ} \mathrm{C}$ to dryness. Digestions were performed using a heating block (Model 1016, Tecator, Höganäs, Sweden) with an exhaust-collecting manifold. Digests were resuspended in $10 \mathrm{ml}$ of redistilled $2 \% \mathrm{HNO}_{3}$. Elemental analysis was performed using inductively coupled plasma - optical emission spectroscopy (ICP-OES; CIROS ICP Model FCE12; Spectro, Kleve, Germany). Five plants were grown for each treatment as described before. Material from each plant was ground and five independent digestions were performed prior to ICP-OES analysis.

\section{AtFRO2 AND GmFer EXPRESSION ANALYSIS}

RNA from roots, leaves, seeds, root tips, pod walls, and petals of control and transgenic plants grown hydroponically under various iron concentrations (see above) was isolated using the RNA-easy kit (Qiagen Inc., Valencia, CA, USA) according to the manufacturer's instructions. RNA was isolated from 3 plants in each treatment. The experiments were repeated twice, and PCR reactions were performed at least in triplicate. Possible contaminating genomic DNA was removed with the TURBO DNA-free ${ }^{\mathrm{TM}}$ kit from Ambion (Ambion Inc., Austin, TX, USA) following the manufacturer's instructions. Total RNA $(0.5 \mu \mathrm{g})$ were subjected to reverse transcription (RT) with an anchored oligo (dT) primer and 200 units superscript II reverse transcriptase (Invitrogen, Carlsbad, CA, USA) in a volume of $20 \mu \mathrm{l}$ according to the manufacturer's instructions. PCR reactions were carried out with $1.5 \mu \mathrm{l}$ of the RT reaction solutions. Additional reaction components were: $10 \mathrm{mM}$ polymerase buffer, 1 mM dNTP's, 0.1 units Taq polymerase (Clontech, Palo Alto, CA, USA) and $1 \mu \mathrm{M}$ specific primers. All primers surrounded an intron so that genomic DNA was clearly distinguished from cDNA-derived products. The following primer sets were designed: ferritin ( $\mathrm{GmFer}$ ), 5'-ACTTGCTCTGTTTCTCTGAGC$3^{\prime}$ (forward), 5'-CGCTAGACGGTGTGACACGT-3' (reverse); ubiquitin ( $\mathrm{GmUbq}$ ), 5'-GGGTTTTAAGCTCGTTGT-3' (forward) and $5^{\prime}$-GGACACATTGAGTTCAAC-3' (reverse). The number of cycles in each PCR reaction was 28 , with $58^{\circ} \mathrm{C}$ annealing temperature. Amplified products from $10 \mu \mathrm{l}$ of PCR reaction were visualized on a $1 \%$ TAE agarose gel containing ethidium bromide. Bands were photographed using the Quantity One 4.5.1 Chemidoc EQ ${ }^{\mathrm{TM}}$ Software System (Biorad, CA, USA).

Quantitative RT-PCR (Q-RT PCR) was performed for AtFRO2 transcript quantification in different plant tissues. Reactions were carried out in an ABI PRISM ${ }^{\circledR} 7700$ sequence detector using TaqMan One Step PCR master Mix reagents Kit and an ABI PRISM ${ }^{\circledR}$ 96-well optical reaction plate (all from Applied Biosystems, Foster City, CA, USA). Validation of the Q-RT PCR methodology was performed in order to find the appropriate RNA concentration at which there is a linear correlation between ribosomal RNA control (18S rRNA) and AtFRO2 transcription. Reactions were carried out with $0.2 \mathrm{ng} / \mu \mathrm{l}$ RNA to a final volume of reaction of $25 \mu \mathrm{l}$. Specific primers designed for AtFRO2 were: 5'-CGTATCAAGTTTGGAACATCCACTT$3^{\prime}$ (forward) and 5'-CCATCATTGGGAACATATACATGAA-3' (reverse), amplifying the TaqMan Probe AtFRO2 sequence of 5'-AAGTTTGGAACATCCACTTATTTTGGTGCCA-3'. For signal detection and quantification, Applied Biosystems-Sequence Detection Systems 1.9.1 was used (Applied Biosystems, Foster City, CA, USA). The following standard thermal profile was used for all PCRs: 40 cycles starting at $48^{\circ} \mathrm{C} 30 \mathrm{~min}, 95^{\circ} \mathrm{C}$ $10 \mathrm{~min}, 95^{\circ} \mathrm{C} 15 \mathrm{~s}$ and $60^{\circ} \mathrm{C}$ for $1 \mathrm{~min}$. The $\Delta \mathrm{Ct} \pm \mathrm{SD}$ and mean transcript level were calculated between four technical replicates from two experiments. To generate a baselinesubtracted plot of the logarithmic increase in fluorescence signal $\left(\Delta \mathrm{R}_{n}\right)$ versus cycle number, baseline data were collected between cycles 3 and 15. All amplifications were analyzed with an $\mathrm{R}_{n}$ threshold of 0.02 to obtain the $\mathrm{C}_{\mathrm{T}}$ (threshold cycle) values.

\section{ORGANIC ACID ANALYSIS}

Leaf and root tissue of control (Thorne) and transgenic (392-3) soybean plants grown hydroponically at $0,10,32$, or $100 \mu \mathrm{M}$ Fe (III)-EDDHA for 2 weeks were used for citrate and malate analysis. Five samples of each tissue were frozen in liquid nitrogen and ground in a ceramic mortar and pestle with $8 \mathrm{mM}$ sulfuric acid. Homogenates were boiled for $30 \mathrm{~min}$, filtered with a $0.2 \mu \mathrm{m}$ filter (Falcon, USA), taken to a final volume of $2 \mathrm{ml}$ with $8 \mathrm{mM}$ sulfuric acid and kept at $-80^{\circ} \mathrm{C}$ until HPLC analysis.

Organic anions were analyzed with an Acclaim OA $5 \mu \mathrm{m}$ ionexchange column $(250 \times 4 \mathrm{~mm}$, DIONEX, TX, USA $)$ with an HPLC system (ICS 3000 Ion Chromatography System, DIONEX, Houston, TX, USA), and Chromeleon software. Samples were manually injected (10- $\mu$ l loop). Mobile phase (100 $\mathrm{mM} \mathrm{Na}_{2} \mathrm{SO}_{4}$, $\mathrm{pH} 2.65)$ was pumped with an isocratic $0.5 \mathrm{ml} \mathrm{min}^{-1}$ flow rate. Organic anions were detected at $210 \mathrm{~nm}$. Peaks corresponding to citrate and malate were identified by comparison of their retention times with those of known standards from Bio-Rad and Sigma (St. Louis). Quantification was made with known amounts of each organic anion using peak areas. 


\section{STATISTICAL ANALYSIS}

Welch's $t$-test and the Dunnett- $C$ test to compare the means were used to compare the leaf, pod wall, root, stem and seed nutrient levels between transgenic and WT plants. A Pearson's correlation analysis with four significance levels $(P<0.05 ; P<0.01$; $P<0.001$, and $P<0.0001$ ) was performed to determine the correlation between 10 different minerals in different tissue types. The mineral data used for the correlation study integrated the ICP results from WT and 392-3 plants grown to maturity at the three iron concentrations, and at the three harvest dates. All statistical analyses were performed using GraphPad Prism 6, version 6.1 (La Jolla, CA, USA).

\section{RESULTS \\ PLANT ORGAN WEIGHT}

Fourteen days after transfer to the hydroponics solution, WT and 392-3 plants appeared similar to each other, in terms of plant size and leaf color, particularly at $100 \mu \mathrm{M} \mathrm{Fe}$ (III)-EDDHA (Figure 1). However, both WT and 392-3 plants grown in the complete absence of iron were already showing severe signs of chlorosis (Figure 1); therefore, this treatment had to be discontinued for the analysis that involved growing the plants to FM.

To test if the constitutive expression of AtFRO2 and a combination of different Fe supplies would influence dry mass accumulation in soybean organs, we cultivated WT and 392-3 plants with 10, 32, or $100 \mu \mathrm{M}$ Fe(III)-EDDHA until FM. The lowest Fe supplies $(10$ and $32 \mu \mathrm{M})$ resulted in significant differences in root dry weight (DW) between the WT and 392-3 line, while no differences were seen between genotypes in the roots at the highest Fe supply of $100 \mu \mathrm{M}$ Fe (III)-EDDHA (Figure 2). The transgenic plants also had significantly heavier shoot DW $(P<0.001)$ than the WT, regardless of the Fe concentration in the growth solution. At 10 and $32 \mu \mathrm{M}$ Fe (III)-EDDHA the transgenic soybean line 392-3 had significantly higher pod wall DW. High Fe supply caused a decrease of about $30 \%$ in root DW in the transgenic line compared to the lower concentrations $(10$ or $32 \mu \mathrm{M})$. In the WT plants, this reduction in root DW was not observed. In fact, WT plants exhibited higher root DW (12.5 $\pm 0.8 \mathrm{~g}$ and $12.2 \pm 0.1 \mathrm{~g})$ when grown in higher

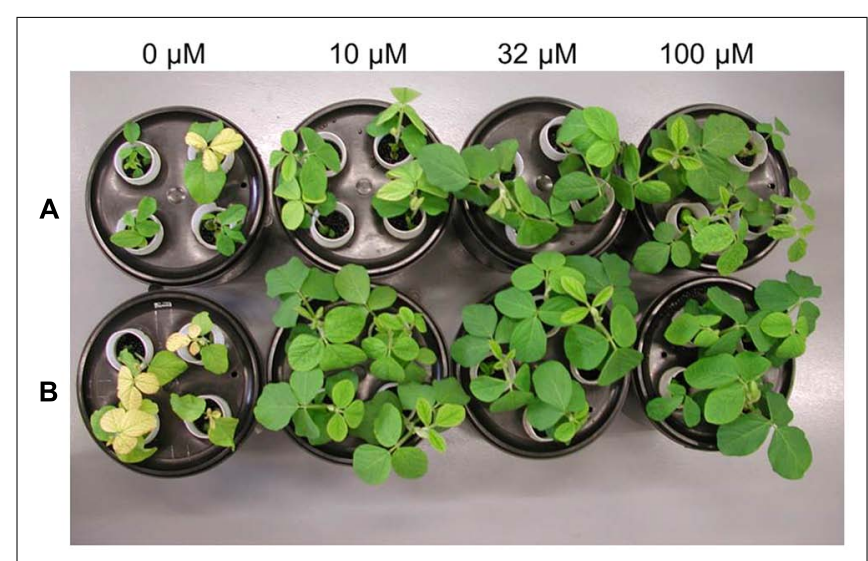

FIGURE 1 | Wild-type (Panel A) and transgenic 392-3 (Panel B) soybean plants at 14 days of hydroponic growth supplemented with $0,10,32$, or $100 \mu \mathrm{M}$ Fe(III) EDDHA (left to right).
Fe concentrations than when grown at $10 \mu \mathrm{M}$ concentration $(9.4 \pm 0.3 \mathrm{~g})$.

\section{AtFRO2 AND GmFer EXPRESSION}

Quantitative RT-PCR revealed that the CaMV 35S promoter drove AtFRO2 expression in different organs of the transgenic plants such as root tips, basal regions of roots (without tips), leaves, petals, pod walls, and seeds, and that AtFRO2 transcript levels were relatively similar amongst the different organs (Figure 3 ). However, when looking at different root regions, it was found that AtFRO2 was less expressed in root tips than in the remaining regions of the root. No expression of AtFRO2 was found in the non-transformed control.

In order to determine if the constitutive expression of AtFRO2 is influenced by the external supply of iron, quantitative RT-PCR was performed in roots and shoots of transgenic soybean line 3923 grown at $0,10,32$, or $100 \mu \mathrm{M} \mathrm{Fe}$ (III)-EDDHA for 14 days. Similar transcript levels were observed in both roots and shoots, regardless of iron concentration in the hydroponics solution (Figure 4).

Ferritin expression was assessed in roots and shoots of control and transgenic plants (Figure 5). Higher ferritin levels were found in the shoots than in the roots in both control and transgenic plants, and an increase in ferritin expression was found when plants were grown at higher iron concentrations. Moreover, 392-3 plants appeared to have higher expression of the ferritingene when compared to control.

\section{TISSUE MINERAL CONCENTRATIONS}

At an initial stage of our experiments, 392-3 soybeans were grown along with the WT plants for 14 days at $32 \mu \mathrm{M} \mathrm{Fe(III)-EDDHA}$ in hydroponic conditions and plants were screened for possible modulatory effects on mineral concentrations in roots, stems, and leaves (Table 1). It was observed that the transgenic line had significantly higher concentrations of $\mathrm{Fe}, \mathrm{Zn}, \mathrm{P}, \mathrm{K}$, and $\mathrm{Mn}$ in leaves, roots and stems, with concentrations increasing more than $50 \%$ when compared to the WT.

The 392-3 soybeans were also grown along with the WT plants at 10,32 , or $100 \mu \mathrm{M}$ Fe (III)-EDDHA in hydroponic conditions and plants were screened up to FM. Iron and $\mathrm{Zn}$ determinations of the leaves, pod walls and seeds were performed at three different developmental seed filling stages: Grain-Fill I (GF I), Grain-Fill II (GF II), and FM (Figure 6). Significant differences in Fe accumulation in the different tissues was found when comparing WT and 392-3 plants, and differences were particularly significant at the last collection date (FM), and at the highest iron concentration $(100 \mu \mathrm{M})$. For plants that were grown at $100 \mu \mathrm{M} \mathrm{Fe}$, at the last collection date (Table 2; Figure 6) 392-3 plants had up to $1142 \pm 69 \mu \mathrm{g} \mathrm{g}^{-1} \mathrm{Fe}$ in the leaves, whereas the WT plants had $435 \pm 18 \mu \mathrm{g} \mathrm{g}^{-1}$. Nonetheless, the increase in Fe concentration in the leaves of plants grown at $100 \mu \mathrm{M}$ Fe (III)-EDDHA was already significant at the GF I and GF II stages. The pod wall Fe levels also were significantly higher in the 392-3 plants, relative to $\mathrm{WT}$, at 32 and $100 \mu \mathrm{M}$ Fe growth conditions at FM (Figure 6), with values reaching up to $120 \pm 4 \mu \mathrm{g} \mathrm{g}^{-1}$. At FM, an increase of up to $100 \%$ was found in iron levels in the leaves of plants grown at $100 \mu \mathrm{M}$ Fe(III)-EDDHA, a higher than 60\% increase 


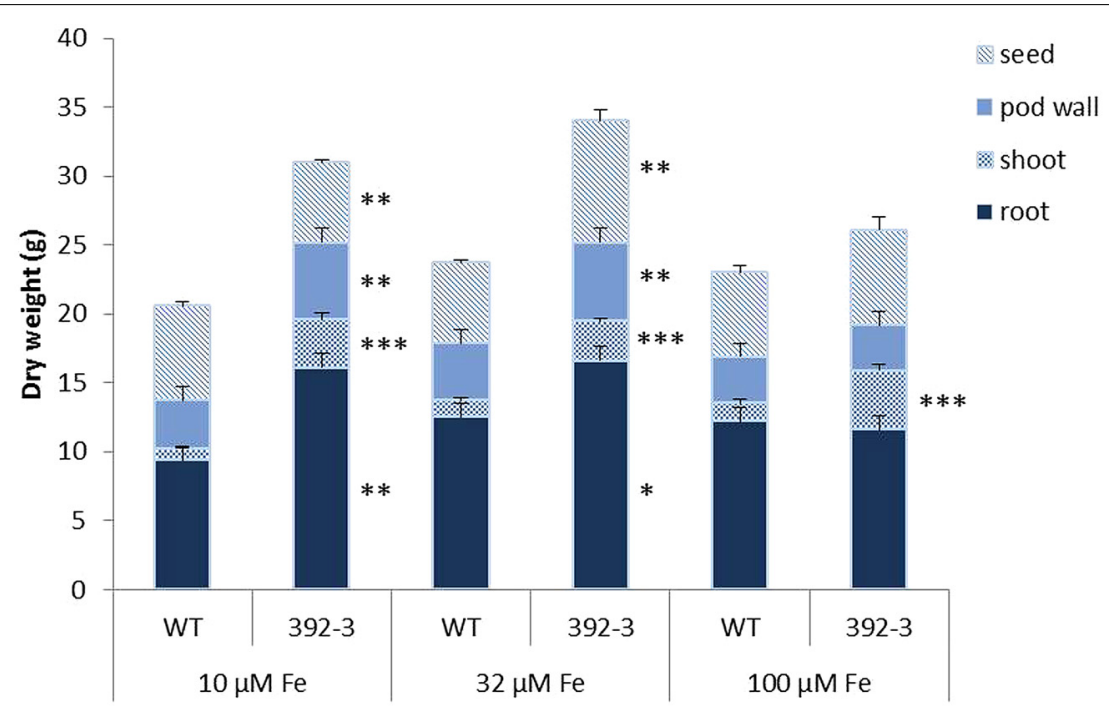

FIGURE 2 | Dry weight of seeds, pod walls, shoot (leaf and stem), and roots collected at full maturity (FM) stages of WT and transgenic 392-3 soybean plants supplied with 10,32 , or $100 \mu \mathrm{M}$ of Fe(III)-EDDHA. Values are the averages of at least five samples \pm SE. Asterisks indicate that the means (between WT and 392-3 within tissue type) are different by the Tukey HSD test $\left({ }^{*} P<0.05 ;{ }^{*} P<0.01 ;{ }^{*}{ }^{*} P<0.001\right)$.

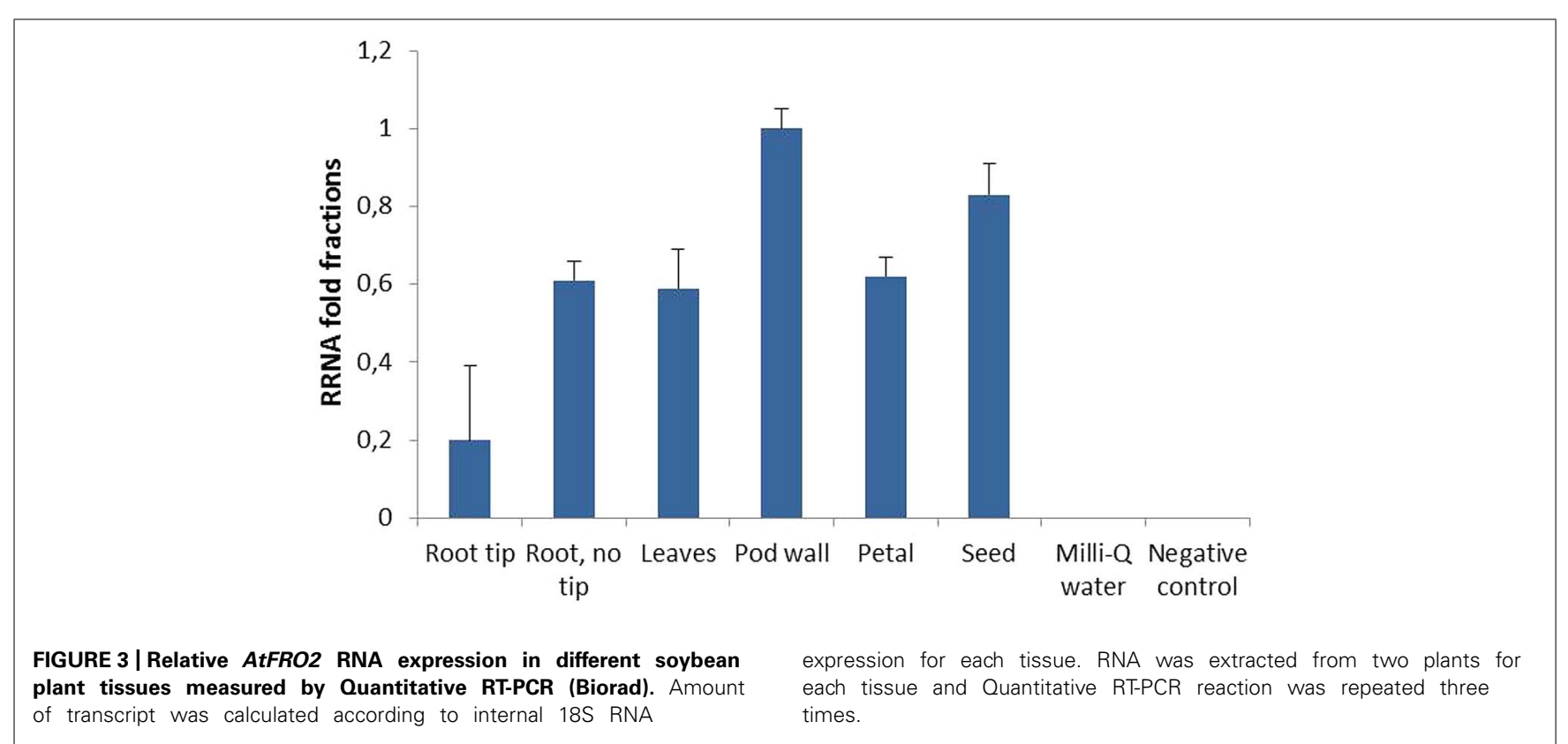

was found in the levels of iron in the pod walls of these same plants, and a 10\% increase was detected in the corresponding seed iron levels. Plants that had been grown in soil, in greenhouse conditions, showed a similar increase in seed iron levels (data not shown).

Zinc concentrations were also higher in the transgenic leaves and seeds but not in the pod walls. The increments were varied with the concentration of iron in the nutrient solution and with the harvest date. In the leaves, increases in $\mathrm{Zn}$ concentration were significantly higher at GF I and GF II, but not at FM. In the seeds, $\mathrm{Zn}$ concentration in 392-3 was always significantly higher than in WT plants grown at the highest Fe concentration.
Because $\mathrm{Fe}$ and $\mathrm{Zn}$ differences were more pronounced in plants grown at $100 \mu \mathrm{M} \mathrm{Fe}$ and at FM, we decided to determine whether other minerals were also affected, looking at this particular stage of development and treatment. Table 2 shows that other minerals besides $\mathrm{Fe}$ and $\mathrm{Zn}$ were also modulated in the transgenic plants, with differences noted in mineral composition in the roots, pod walls, leaves, and seeds (Table 2). In roots, several obvious mineral concentration differences could be detected. High Fe supply, in combination with the constitutive expression of AtFRO2, was associated with higher concentrations of $\mathrm{K}, \mathrm{P}, \mathrm{Zn}, \mathrm{Ca}, \mathrm{Ni}, \mathrm{Mg}$, and $\mathrm{Mo}$. In pod walls, transgenic plants had significantly higher $\mathrm{Fe}, \mathrm{K}, \mathrm{P}, \mathrm{Cu}$, and $\mathrm{Ni}$ concentrations 


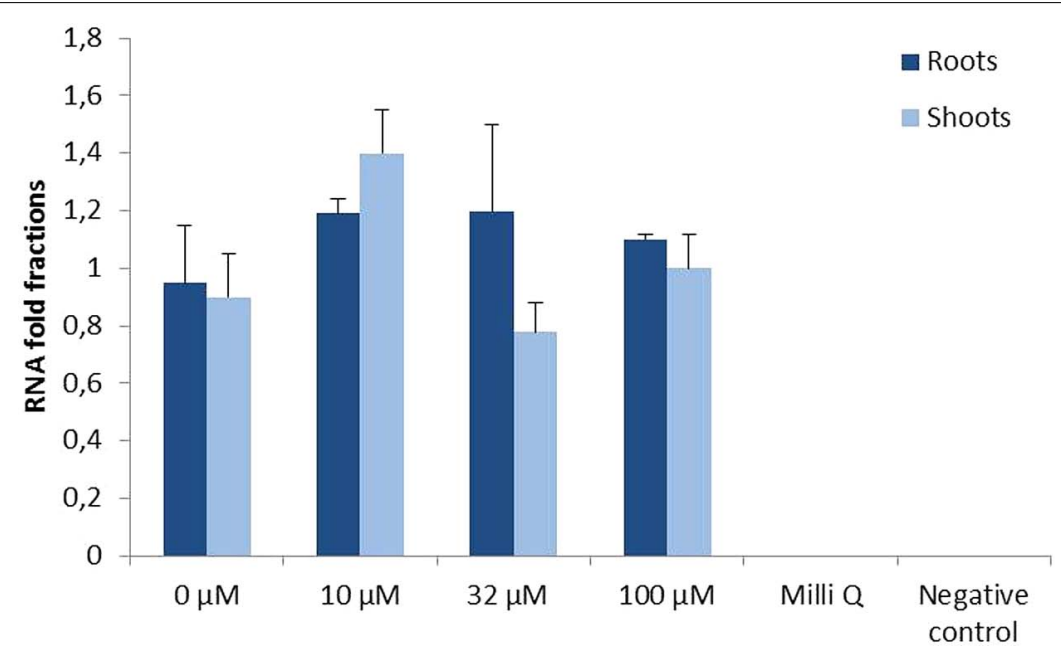

FIGURE 4 | Relative AtFRO2 RNA expression in roots and shoots of transgenic 392-3 soybean plants supplied with $0,10,32$, or $100 \mu \mathrm{M}$ Fe(III) EDDHA detected by Quantitative RT-PCR (Biorad). Amount of transcript was calculated according to internal 18S RNA expression for each tissue. RNA was extracted from 2 plants for each tissue and Quantitative RT-PCR reaction was repeated three times.

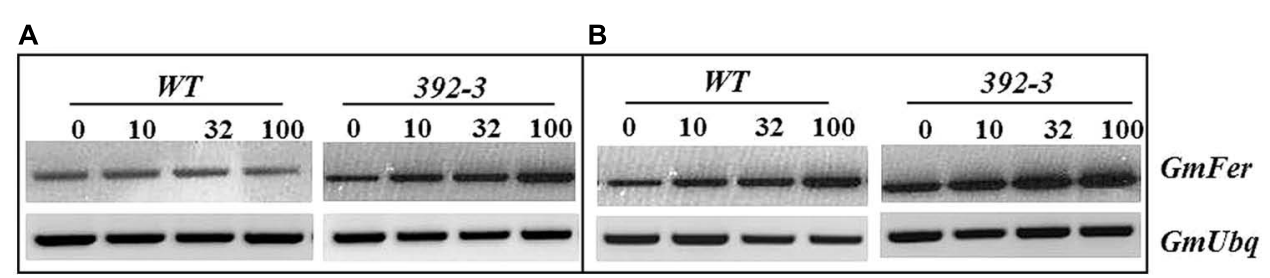

FIGURE 5 | Semi-quantitative RT-PCR analysis of the soybean ferritin (GmFer) expression in roots (Panel A) and shoots (Panel B) of WT and 392-3 G. max plants grown under different iron concentrations [0, 10, 32, or $\mathbf{1 0 0} \mu \mathbf{M}$ Fe (III)-EDDHA]. Soybean ubiquitin gene (GmUbq) was used as template loading control.

Table 1 | Average root, stem, and leaf mineral concentration of wild-type (WT) and 392-3 transgenic soybean plants grown in hydroponic conditions with $32 \mu \mathrm{M}$ Fe(III)-EDDHA for 2 weeks.

\begin{tabular}{|c|c|c|c|c|c|c|}
\hline \multirow{2}{*}{$\begin{array}{l}\text { Mineral } \\
\left(\mu \mathbf{g ~ g}^{-1}\right)\end{array}$} & \multicolumn{2}{|c|}{ Roots } & \multicolumn{2}{|c|}{ Stems } & \multicolumn{2}{|c|}{ Leaves } \\
\hline & WT & $392-3$ & WT & $392-3$ & WT & $392-3$ \\
\hline $\mathrm{Mn}$ & $122 \pm 10$ & $258 \pm 13^{* *}$ & $122 \pm 10$ & $258 \pm 13^{* *}$ & $65 \pm 2$ & $188 \pm 8^{* *}$ \\
\hline K & $46430 \pm 7979$ & $51266 \pm 2875^{*}$ & $33692 \pm 2556$ & $46004 \pm 2467^{*}$ & $27244 \pm 389$ & $30575 \pm 1306^{*}$ \\
\hline $\mathrm{Zn}$ & $100 \pm 4$ & $346 \pm 11 * *$ & $56 \pm 3$ & $149 \pm 9 * *$ & $136 \pm 3$ & $283 \pm 6^{* *}$ \\
\hline
\end{tabular}

Values are shown as mean $\pm S E$ and represent an average of five plants. Significance within tissue types: ${ }^{*} P<0.05 ;{ }^{*} P<0.01$.

and significantly lower concentrations of $\mathrm{Ca}$ and $\mathrm{Mg}$. In leaves there was a significant increase in leaf $\mathrm{Fe}$, but also in $\mathrm{P}, \mathrm{Cu}, \mathrm{Ca}$, $\mathrm{Ni}$, and $\mathrm{Mg}$. In seeds, the concentrations of $\mathrm{Fe}, \mathrm{Zn}, \mathrm{Cu}$, and $\mathrm{Ni}$ were significantly increased in the transgenic line, relative to WT.

\section{MINERAL CORRELATION ANALYSIS}

Pearson's correlation analysis was performed in order to find relationships among the ten minerals' concentrations in three different plant tissues. The organ with the fewest number of correlations was the seed; however, it was also the organ where the most significant correlations occurred (Figure 7). In general, Fe seems to be very tightly linked to several other minerals, with particular emphasis in the leaves and pod walls. As can be observed in Figure 7, the only positive correlations that are common for the three tissue types are the pairs $\mathrm{Fe}-\mathrm{Zn}, \mathrm{Fe}-\mathrm{Cu}$, and $\mathrm{Ni}-\mathrm{Cu}$. Other correlations are common in two of the three tissues. 


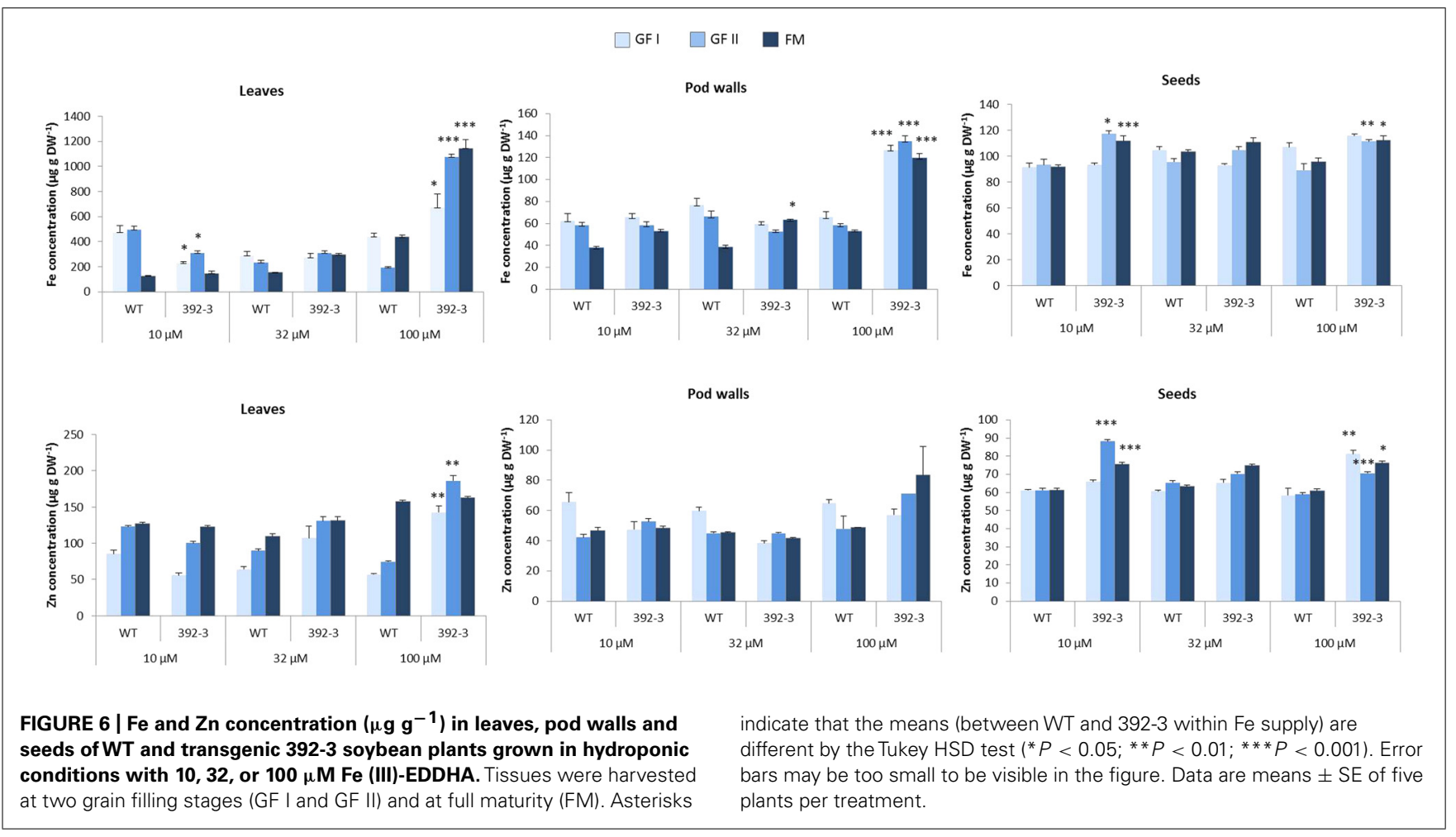

Table 2 | Mineral concentration $\left(\mu \mathrm{g} \mathrm{g}^{-1}\right)$ in roots, pod walls, leaves, and seeds of wild-type (WT) and transgenic 392-3 soybean plants grown in hydroponic conditions with $100 \mu \mathrm{M}$ Fe(III)-EDDHA until full maturity (FM).

\begin{tabular}{|c|c|c|c|c|c|c|c|c|}
\hline \multirow{2}{*}{$\begin{array}{l}\text { Mineral } \\
\left(\mu \mathbf{g ~ g}^{-1}\right)\end{array}$} & \multicolumn{2}{|c|}{ Roots } & \multicolumn{2}{|c|}{ Pod walls } & \multicolumn{2}{|c|}{ Leaves } & \multicolumn{2}{|c|}{ Seeds } \\
\hline & WT & $392-3$ & WT & $392-3$ & WT & $392-3$ & WT & $392-3$ \\
\hline $\mathrm{Mn}$ & $10 \pm 0.6$ & $9 \pm 0.3$ & $22 \pm 2$ & $17 \pm 1$ & $49 \pm 6$ & $47 \pm 1$ & $20 \pm 1$ & $24 \pm 1^{*}$ \\
\hline K & $13256 \pm 83$ & $41661 \pm 2644^{*}$ & $26722 \pm 436$ & $32064 \pm 620^{* *}$ & $15385 \pm 200$ & $13336 \pm 977$ & $18920 \pm 415$ & $19341 \pm 78$ \\
\hline $\mathrm{Zn}$ & $45 \pm 1$ & $137 \pm 50^{*}$ & $49 \pm 1$ & $84 \pm 19^{* *}$ & $157 \pm 3$ & $162 \pm 2$ & $61 \pm 1$ & $76 \pm 1^{* *}$ \\
\hline $\mathrm{Cu}$ & $27 \pm 1$ & $25 \pm 2$ & $8 \pm 0.1$ & $13 \pm 0.3^{* *}$ & $3 \pm 0.1$ & $8 \pm 0.4^{* *}$ & $15 \pm 0.1$ & $17 \pm 0.1 * * *$ \\
\hline $\mathrm{Ca}$ & $9788 \pm 72$ & $7553 \pm 200^{*}$ & $23605 \pm 395$ & $19275 \pm 124^{* *}$ & $21861 \pm 330$ & $30398 \pm 591 * *$ & $3519 \pm 57$ & $3674 \pm 61$ \\
\hline $\mathrm{Ni}$ & $2 \pm 0.4$ & $3 \pm 0.2^{*}$ & $3 \pm 0.1$ & $5 \pm 0.1 * *$ & $1 \pm 0.1$ & $2 \pm 0.2^{* *}$ & $8 \pm 0.1$ & $9 \pm 0.1^{*}$ \\
\hline $\mathrm{Mg}$ & $435 \pm 0.5$ & $534 \pm 12^{*}$ & $4886 \pm 61$ & $4310 \pm 59^{*}$ & $1648 \pm 28$ & $2346 \pm 120^{*}$ & $2190 \pm 21$ & $2103 \pm 16$ \\
\hline
\end{tabular}

Values are shown as mean $\pm S E$ and represent an average of five plants. Significance within tissue types: ${ }^{*} P<0.05 ;{ }^{*} P<0.01 ;{ }^{* *} P<0.001$

\section{LEAF IRON REDUCTION ACTIVITY}

The small differences in the seed iron concentration between WT and 392-3 transgenic plants led to the hypothesis that perhaps the higher reductase activity in the roots may not be paralleled by a higher reductase activity in the leaves or in other plant organs, which could be sources of transportable Fe. If the increased iron concentration in the leaves of the 392-3 plants is being stored in a non-transportable form, then there will not be a concomitant transport to the developing seeds. Therefore, an optimized protocol was used to measure ferric chelate reductase activity of soybean plants grown in hydroponics for two weeks at 10,32 , or $100 \mu \mathrm{M}$ Fe (III)-EDDHA. Protoplasts isolated from leaf cells of 392-3 and WT plants showed that expression of AtFRO2 increased leaf iron reduction capacity up to 3-fold when compared to the WT, regardless of the plant iron treatment (Figure 8).

\section{CHANGES IN LEAF AND ROOT ORGANIC ACIDS}

Malate and citrate have been described as important compounds in the translocation of Fe in the plant's vascular system. Both OA were 


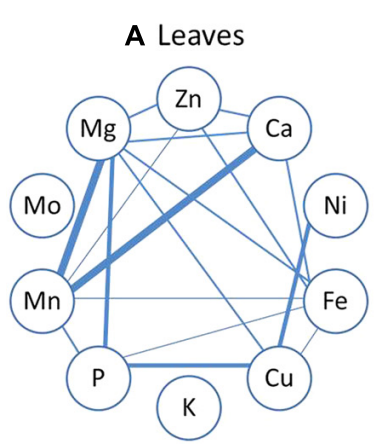

FIGURE 7 | Mineral correlation analysis. Pearson's correlation analysis of ten mineral concentrations in leaves (A), pod walls (B), and seeds (C) of Thorne and 392-3 soybean plants cultivated with 10,32 , or $100 \mu \mathrm{M}$ of Fe (III)-EDDHA and measured at two grain filling stages (GF I and GF II) or at full maturity (FM). Solid lines represent a significant positive
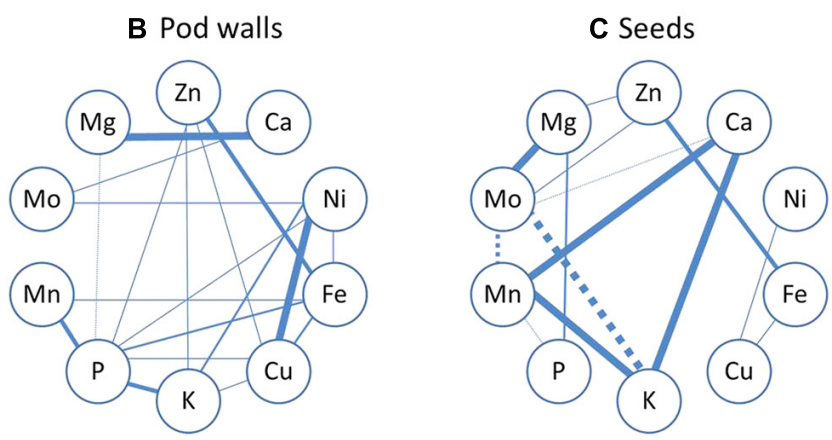

correlation and dashed lines represent a significant negative correlation. Thinner lines indicate significance at the $P<0.05$, semi-thin indicate significance at the $P<0.01$, semi-thick indicate significance at the $P<0.001$ level and the thicker lines indicate significance at the $P<0.0001$ level.

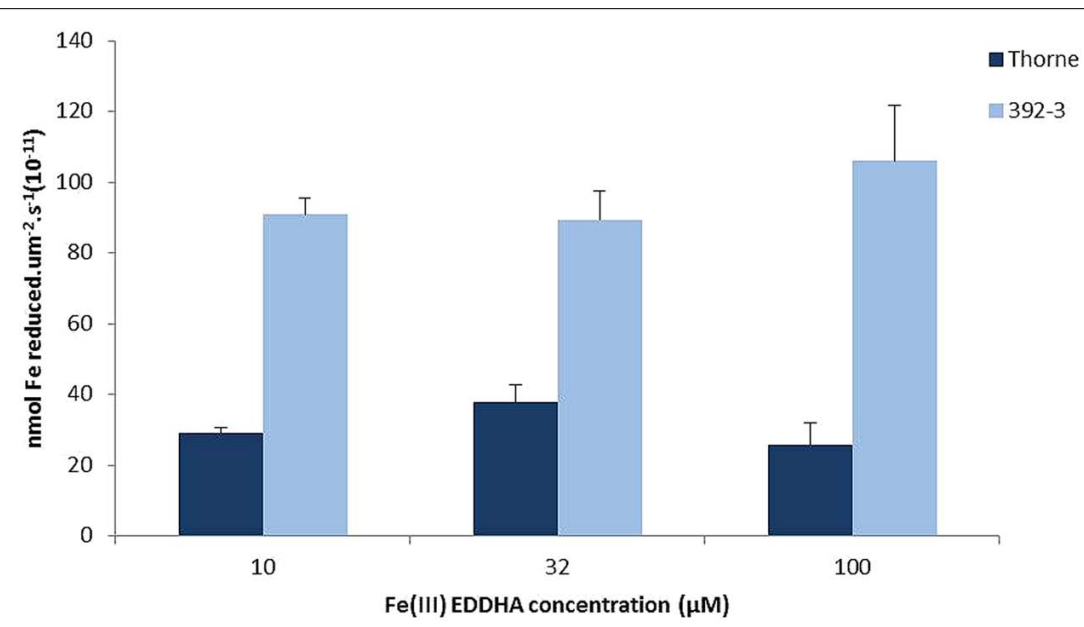

FIGURE 8 | Iron reductase activity measured in vivo in protoplasts isolated from WT and transgenic 392-3 soybean leaves of plants grown with 10, 32 , or $100 \mu \mathbf{M}$ Fe (III)-EDDHA. Values are shown per surface area. Measurements were made with $400 \mu \mathrm{M}$ Fe (III)-EDTA as a substrate. Data are means \pm SE of three replications each.

detected in transgenic and control leaves and roots. In general, differences between 392-3 and WT plants were more pronounced in the leaves than in the roots, and transgenic plants accumulated significantly higher amounts of both OA than WT. In the leaves of 392-3 plants, citrate and malate were higher when plants were grown at 10, 32, or $100 \mu \mathrm{M}$ Fe (Figures 9A,B). A different pattern was observed in the WT plants: malate concentrations were highest in leaves of iron-starved plants, and were lower when iron was available to the plants. Leaf citrate concentrations were only elevated at $32 \mu \mathrm{M}$ Fe.

For plants grown in the absence of Fe, citrate, and malate were not detectable in the roots of WT and transgenic plants. However, when plants were grown in Fe sufficiency, both OA were observed (Figures 9A,B).

\section{DISCUSSION}

There is currently a strong interest in developing strategies to increase the level of minerals, such as iron, in edible plant organs.
One such strategy is the over-expression of genes that are necessary for proper plant iron status. Previous work has shown that by enhancing the reductase activity in transgenic soybean, plants are able to cope better in iron limiting soils, having higher chlorophyll values and improved agronomic performance (Vasconcelos et al., 2006). Also, a possible strategy to enhance the mineral content of plant foods is to enhance the uptake of minerals from the roots during the period of seed development (Waters and Grusak, 2008; Sperotto et al., 2012).

\section{MINERAL CONCENTRATIONS AND CORRELATIONS}

In the current study, soybean plants overexpressing AtFRO2 were analyzed for mineral concentrations (Fe, $\mathrm{Zn}, \mathrm{Cu}, \mathrm{Mn}, \mathrm{Mg}$, $\mathrm{Ca}, \mathrm{Mo}, \mathrm{Ni}, \mathrm{K}$, and $\mathrm{P}$ ) in source and sink tissues at different seed-filling stages. Significant differences were found in the mineral concentration of transgenic plants when compared to the WT, and differences were particularly prominent when tissues were collected at the final developmental stage (Table 1). 

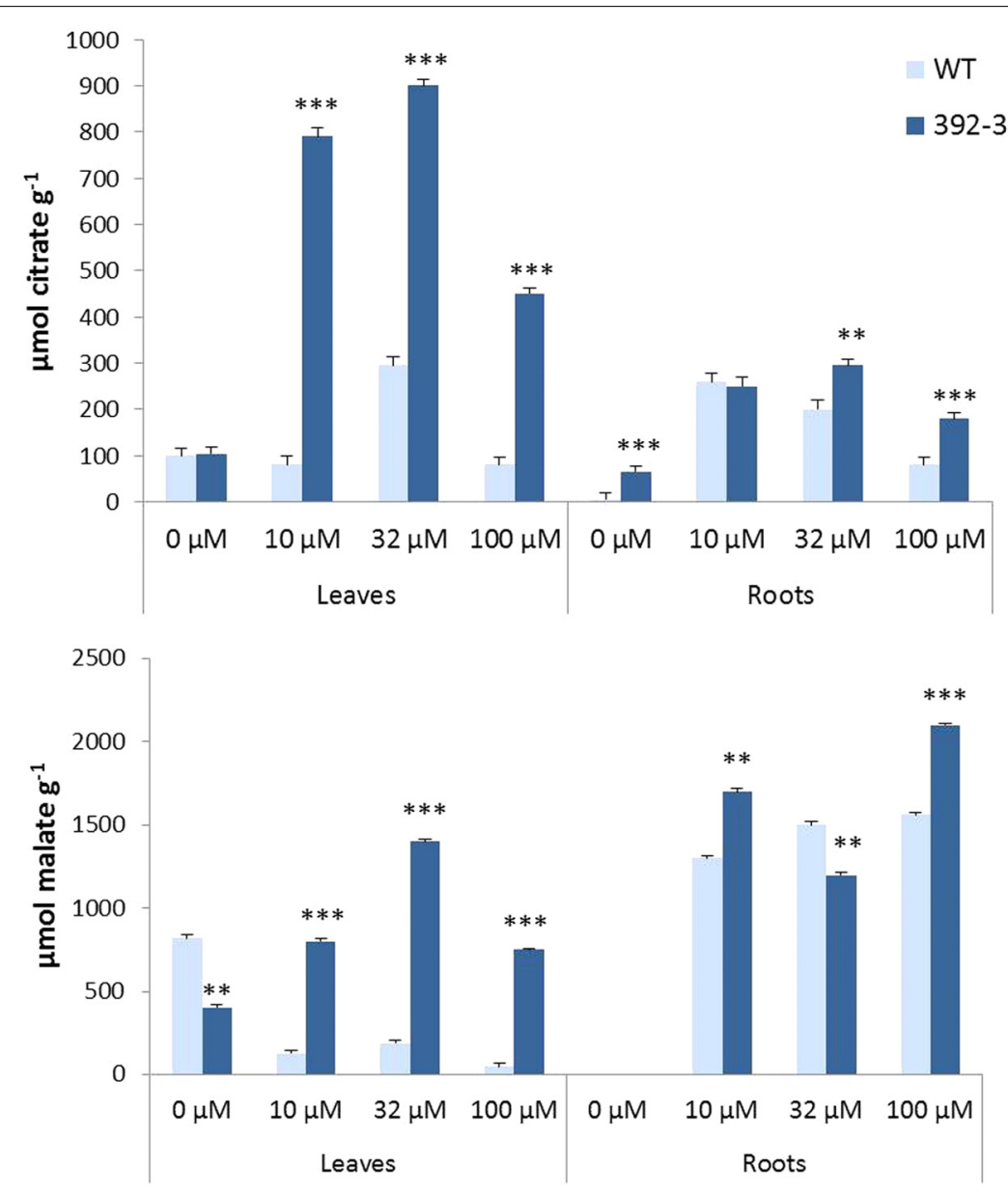

FIGURE 9 | Effects of Fe concentration on organic acid (citrate and malate) accumulation in WT and 392-3 soybean leaves and roots. Data are means \pm SE of eight replicates. Asterisks represent significant differences between WT and $392-3\left({ }^{* *} P<0.01 ; * * * P<0.001\right)$.

This suggests that the iron reductase is not only involved in iron acquisition, but it plays a more general role in the regulation of ion absorption by root cells. This hypothesis has been supported by others (Marschner et al., 1982; Stephan and Grün, 1989; Welch and LaRue, 1990; Yi and Guerinot, 1996). Furthermore, after two weeks in hydroponic conditions supplemented with $0,10,32$, or $100 \mu \mathrm{M}$ Fe (III)-EDDHA, the transgenic line 392-3 had significantly higher concentrations of $\mathrm{Fe}, \mathrm{Zn}$, and $\mathrm{Mn}$ in leaves, roots, and stems, with concentrations 50\% higher when compared to the WT (Table 1). Increased Mn uptake and subsequent translocation to the aerial parts of the plant is reasonable, because Mn moves easily from roots to shoot tissues in the xylem-sap transpiration stream (Ramani and Kannan, 1987; Marschner, 1995).

After observing that 392-3 had altered concentrations of different minerals after 14 days of growth, we grew plants to maturity and analyzed mineral accumulation in roots, leaves, pod walls, and seeds at different developmental seed filling stages (Figure 6). At the last harvest date (FM), it was observed that when grown with high Fe supply, in combination with the constitutive expression of AtFRO2, there were several significant mineral changes. In pod walls, transgenic plants had significantly higher $\mathrm{Fe}, \mathrm{K}, \mathrm{P}, \mathrm{Cu}$, and $\mathrm{Ni}$; however, significantly lower concentrations of $\mathrm{Ca}$ and $\mathrm{Mg}$ were found (Table 2), suggesting an antagonistic effect of the higher Fe concentrations in these tissues, or that pod transpiration rates were depressed. Finally, besides Fe, seeds had also significantly higher concentrations of $\mathrm{Zn}, \mathrm{Cu}$, and $\mathrm{Ni}$.

There were two minerals which were significantly higher across all tissues of 392-3 when compared to WT (roots, leaves, pod walls, and seeds): Ni and P. In fact, Ni rapidly re-translocates from leaves to young tissues in the phloem, particularly during reproductive growth. Up to $70 \%$ of $\mathrm{Ni}$ in the shoots is transported to the seeds of soybean (Tiffin, 1971).

In the case of $\mathrm{P}$, more $\mathrm{P}$ becomes available for uptake when there is an increase of OA exudation (Remy et al., 2012). Thus, our observations of significantly higher OA production by 392-3 roots and leaves (Figure 9) could explain the increased uptake of P. If this hypothesis is true, then it suggests that the most important source of $\mathrm{P}$ for the seeds is the $\mathrm{P}$ taken up during seed fill, and not remobilized $\mathrm{P}$. In fact, in previous work where $\mathrm{P}$ was either remobilized or not from the leaves, no changes in $\mathrm{P}$ occurred in soybean seeds (Crafts-Brandner, 1992). 
When looking at mineral correlations (Figure 7), the positive correlations which were common in leaves, pod walls and seeds were the pairs $\mathrm{Fe}-\mathrm{Zn}, \mathrm{Fe}-\mathrm{Cu}$, and $\mathrm{Ni}-\mathrm{Cu}$. Ni-Cu share a common uptake system (Kochian, 1991), and Fe-Zn as well, because the IRT1 Fe transporter also mediates Zn transport (Eide et al., 1996; Korshunova et al., 1999; Vert et al., 2002). The link between $\mathrm{Fe}-\mathrm{Cu}$ cannot be explained by common transporters, as it has been shown that IRT1 (at least in Arabidopsis) cannot transport Cu. However, 35S-FRO2 transgenic Arabidopsis plants have elevated $\mathrm{Cu}$ reductase activity (Connolly et al., 2003; Zimmermann et al., 2009), and at 14d 392-3 plants also have enhanced $\mathrm{Cu}$ reductase activity (data not shown), which may have increased the amount of available $\mathrm{Cu}$ for uptake, transport and accumulation.

In leaves and pod walls, there was a positive correlation between $\mathrm{Fe}-\mathrm{Mn}$, contrary to what was found in rice (Sperotto et al., 2012). In seeds, there was a positive correlation between $\mathrm{Ca}$ and $\mathrm{Mn}$, which is in agreement with Zeng et al. (2005) and Majumder et al. (1990). Also in the seeds, there was a positive correlation between $\mathrm{Ca}$ and $\mathrm{K}$, confirming what was seen before in rice (Sperotto et al., 2012).

The mineral correlations in the different plant organs could also be related to differential mobilities within the plant, and several mineral elements, such as $\mathrm{Ca}$ and Mo, are not very phloem mobile (Marschner, 1995; Lucas et al., 2013). Once deposited in the leaves, minerals must be remobilized to the seeds via phloem transport, and $\mathrm{K}, \mathrm{Na}, \mathrm{Mg}, \mathrm{P}$, are transported readily, but $\mathrm{Fe}, \mathrm{Zn}, \mathrm{Cu}$, and $\mathrm{Mo}$ are less mobile, and $\mathrm{Mn}$ and $\mathrm{Ca}$ are poorly mobile in the phloem of most plant species (Marschner, 1995). Mineral elements that have low phloem mobilities generally accumulate in tissues with high transpiration rates (White and Broadley, 2009).

\section{THE ROLE OF SHOOT Fe REDUCTASE ACTIVITY}

An interesting question that arises from this study is why 392-3 acquired only $10 \%$ more iron in the seeds when leaves and pod walls were more highly enriched in iron. Why did this excess iron not move to the seeds? It has been shown previously that in soybean (Lazlo, 1990), the developing ovules exhibit a gradual increase in seed Fe accretion as long as seed DW is increasing. In the current study, the source tissues of the transgenic plants showed more than double the iron concentration when compared to control plants (Table 1), and in certain instances, a 5-fold increase was observed in iron concentrations in the leaves. The small (yet significant) differences in the seed iron concentration between WT and 392-3 plants suggested that perhaps the higher reductase activity in the roots (Vasconcelos et al., 2006) may not have been paralleled by a higher reductase activity in the leaves. However, protoplasts isolated from leaf cells of 392-3 and WT plants showed that AtFRO2 expression increased leaf iron reduction capacity up to 3 -fold, relative to WT (Figure 1). However, it appears that having higher iron reduction capacity in the leaves (and presumably other vegetative tissues) may confer only a modest benefit in the availability and/or loading of iron to the phloem and subsequent transport to the seeds. Fe remobilization from leaves to seeds has been seen in legumes (Hocking and Pate, 1977; Grusak, 1994), and remobilization from leaves to seeds increases during senescence in common bean (Phaseolus vulgaris L.; Zhang et al., 1995). At FM, in the current study, we already had several senescing leaves, which should be working as sources of Fe to the seeds.

Chelation is a required factor for phloem transport of iron. Using the $b r z$ and $d g l$ Fe-hyperaccumulating pea mutants, it was suggested that Fe must be chelated prior to phloem loading, since transition metal ions precipitate at alkaline $\mathrm{pH}$ values characteristic of phloem saps (Grusak, 1994). It is possible that our transgenic 392-3 soybean plants did not produce enough chelators to transport the excess leaf iron to the seeds. Once iron has entered the plant, both NA and citrate have been proposed to serve as iron chelators; mutants that do not properly synthesize or transport these chelators have lower Fe accumulation in the seeds (Jeong et al., 2008). We have shown that the 392-3 plants have significantly higher citrate and malate concentrations in leaves and roots. Several authors have reported an increase in xylem sap OA concentrations with Fe deficiency (Abadía et al., 2002; López-Millán et al., 2009; Larbi et al., 2010), a condition where there is up-regulation of the Fe reductase. Also, FRO2 belongs to a superfamily of flavocytochrome oxidoreductases, containing a NADPH sequence motif on the inside of the membrane (Schagerlof et al., 2006). It is possible that elevated levels of AtFRO2 lead to increased NADPH consumption, which consequently induces metabolic pathways that lead to a higher production of OA (López-Millán et al., 2000). Because the higher accumulation of malate and citrate did not enable increased seed iron levels, it seems that citrate and malate may not be limiting factors contributing to the transport of $\mathrm{Fe}$ to seeds.

Perhaps other factors need to be turned on for higher phloem Fe translocation from shoots to seeds. In rice, it is known that OsYSL2 expression is a necessary component for correct translocation of Fe to young shoots and developing seeds (Ishimaru et al., 2010; Masuda et al., 2012), as it is thought to transport Fe(II)-NA in the phloem (Koike et al., 2004). If there is a similar need in soybean, it is possible that the expression of this ortholog in our transgenic plants may not have been up-regulated.

\section{IRON STORED AS FERRITIN}

Another factor that could have prevented the remobilization of Fe to the seeds is if Fe was stored in a non-translocatable form, e.g., complexed within ferritin. Ferritin is one of the principal forms of iron storage in plants, and it provides a means of rapidly sequestering iron ions that might otherwise promote the formation of reactive oxygen species (Truty et al., 2001). Ferritin expression was assessed in roots and shoots of control and transgenic plants in order to see if the extra iron could be stored in the form of ferritin (Figure 3). Higher ferritin transcript levels were found in the shoots than in the roots in both control and transgenic plants, and an increase in ferritin expression was found when plants were grown at higher iron concentrations $(100 \mu \mathrm{M} \mathrm{Fe})$. Moreover, $392-$ 3 plants seemed to have higher expression of the ferritin gene, indicating that the excess iron concentration found in the roots and shoots of the transgenic plants is at least partly stored in the form of ferritin, and thus may not be readily available for export. 


\section{CONCLUSION}

Accumulation of iron in the various plant tissues during growth and development is a dynamic process resulting from an integrated regulation of genes encoding proteins for mineral uptake, transport and storage. These processes depend on the plant genotype and are greatly influenced by environmental cues. Can an improved soybean be developed that is fortified with essential minerals? The results presented herein demonstrate that constitutive expression of an iron reductase gene led to a $10 \%$ increase in seed $\mathrm{Fe}, \mathrm{Zn}$, and $\mathrm{Cu}$, and a 20\% increase in Mn levels, despite the fact that mineral concentration in the leaves and pod walls (two of the most important mineral sources for the seeds) reached much higher relative levels in the transgenic plants. This indicates that manipulation of the iron reductase could be an effective biofortification strategy for several minerals, especially when targeting leafy food sources.

\section{ACKNOWLEDGMENTS}

This work was supported in part by funds from USDA-ARS under Agreement number 58-6250-0-008 to MAG. The contents of this publication do not necessarily reflect the views or policies of the US Department of Agriculture, nor does mention of trade names, commercial products, or organizations imply endorsement by the US Government. This work was also financially supported by FCT and FEDER, through the project ref. PTDC/AGR-GPL/118772/2010. We are very thankful to Susana Carvalho for a critical review of the manuscript.

\section{REFERENCES}

Abadía, J., López-Millán, A. F., Rombolà, A., and Abadía, A. (2002). Organic acids and Fe deficiency: a review. Plant Soil 241, 75-86. doi: 10.1023/A:10160933 17898

Brüggemann, W., Maas-Kantel, K., and Moog, P. R. (1993). Iron uptake by leaf mesophyll cells: the role of the plasma membrane-bound ferric-chelate reductase. Planta 190, 151-155. doi: 10.1007/BF00196606

Connolly, E. L., Campbell, N. H., Grotz, N., Prichard, C. L., and Guerinot, M. L. (2003). Overexpression of the FRO2 ferric chelate reductase confers tolerance to growth on low iron and uncovers posttranscriptional control. Plant Physiol. 133, 1102-1110. doi: 10.1104/pp.103.025122

Carvalho, S., and Vasconcelos, M. (2013). Producing more with less: 'omics' at the service of plant-based food biofortification. Food Res. Int. 54, 961-971. doi: 10.1016/j.foodres.2012.12.021

Crafts-Brandner, S. J. (1992). Phosphorus nutrition influence on leaf senescence in soybean. Plant Physiol. 98, 1128-1132. doi: 10.1104/pp.98.3.1128

Curie, C., and Briat, J.-F. (2003). Iron transport and signaling in plants. Annu. Rev. Plant Biol. 54, 183-206. doi: 10.1146/annurev.arplant.54.031902.135018

Curie, C., Cassin, G., Couch, D., Divol, F., Higuchi, K., Le Jean, M., et al. (2009). Metal movement within the plant: contribution of nicotianamine and yellow stripe 1-like transporters. Ann. Bot. 103, 1-11. doi: 10.1093/aob/mcn207

de la Guardia, M., and Alcántara, E. (1996). Ferric chelate reduction by sunflower (Helianthus annuus L.) leaves: influence of light, oxygen, iron-deficiency and leaf age. J. Exp. Bot. 47, 669-675. doi: 10.1093/jxb/47.5.669

Dinkins, R. D., Reddy, M. S. S., Meurer, C. A., Yan, B., Trick, H., Thibaud-Nissen, F., et al. (2001). Increased sulfur amino acids in soybean plants overexpressing the maize $15 \mathrm{kda}$ zein protein. In Vitro Cell. Dev. Biol. Plant 37, 742-747. doi: 10.1007/s11627-001-0123-x

Dwiyanti, M. S., Yamada, T., Sato, M., Abe, J., and Kitamura, K. (2011) Genetic variation of $\gamma$-tocopherol methyltransferase gene contributes to elevated $\alpha$-tocopherol content in soybean seeds. BMC Plant Biol. 11:152. doi: 10.1186/1471-2229-11-152

Eide, D., Broderius, M., Fett, J., and Guerinot, M. L. (1996). A novel iron-regulated metal transporter from plants identified by functional expression in yeast. Proc. Natl. Acad. Sci. U.S.A. 93, 5624-5628. doi: 10.1073/pnas.93.11.5624
Feng, H., An, F., Zhang, S., Ji, Z., Ling, H.-Q., and Zuo, J. (2006). Light-regulated, tissue-specific, and cell differentiation-specific expression of the Arabidopsis Fe(III)-chelate reductase gene AtFRO6. Plant Physiol. 140, 1345-1354. doi: 10.1104/pp.105.074138

Fourcroy, P., Sizó-Terraza, P., Sudre, D., Savirón, M., Reyt, G., Gaymard, F., et al. (2013). New Phytol. 201, 155-167. doi: 10.1111/nph.12471

Gonzalez-Vallejo, E. B., Morales, F., Cistue, L., Abadia, A., and Abadia, J. (2000). Iron deficiency decreases the $\mathrm{Fe}$ (III)-chelate reducing activity of leaf protoplasts. Plant Physiol. 122, 337-344. doi: 10.1104/pp.122.2.337

Grusak, M. A. (1994). Iron transport to developing ovules of Pisum sativum. I. Seed import characteristics and phloem iron-loading capacity of source regions. Plant Physiol. 104, 649-655. doi: 10.1104/pp.104.2.649

Grusak, M. A. (1995). Whole-root iron(III)-reductase activity throughout the life cycle of iron-grown Pisum sativum L. (Fabaceae): relevance to the iron nutrition of developing seeds. Planta 197, 111-117. doi: 10.1007/BF00239946

Hell, R., and Stephan, U. W. (2003). Iron uptake, trafficking and homeostasis in plants. Planta 216, 541-551.

Hocking, P. J., and Pate, J. S. (1977). Mobilization of minerals to developing seeds of legumes. Ann. Bot. 41, 1259-1278.

Hindt, M. N., and Guerinot, M. L. (2012). Getting a sense for signals: regulation of the plant iron deficiency response. Biochim. Biophys. Acta 1823, 1521-1530. doi: 10.1016/j.bbamcr.2012.03.010

Ishimaru, Y., Masuda, H., Bashir, K., Inoue, H., Tsukamoto, T., Takahashi, M., et al. (2010). Rice metal-nicotianamine transporter, OsYSL2, is required for the long-distance transport of iron and manganese. Plant J. 62, 379-390. doi: 10.1111/j.1365-313X.2010.04158.x

Ivanov, R., Brumbarova, T., and Bauer, P. (2012). Fitting into the harsh reality: regulation of iron-deficiency responses in dicotyledonous plants. Mol. Plant 5, 27-42. doi: 10.1093/mp/ssr065

Jeong, J., Cohu, C., Kerkeb, L., Pilon, M., Connolly, E. L., and Guerinot, M. L. (2008). Chloroplast $\mathrm{Fe}$ (III) chelate reductase activity is essential for seedling viability under iron limiting conditions. Proc. Natl. Acad. Sci. U.S.A. 105, 10619-10624. doi: 10.1073/pnas.0708367105

Kobayashi, T., and Nishizawa, N. K. (2012). Iron uptake, translocation, and regulation in higher plants. Annu. Rev. Plant Biol. 63, 131-152. doi: 10.1146/annurev-arplant-042811-105522

Kochian, L. V. (1991). "Mechanisms of micronutrient uptake and translocation in plants," in Micronutrients in Agriculture, 2nd Edn, ed. J. J. Mortvedt, SSSA book series \# 4 (Madison, WI: Soil Science Society of America), 229-296.

Koike, S., Inoue, H., Mizuno, D., Takahashi, M., Nakanishi, H., Mori, S., et al. (2004). OsYSL2 is a rice metal-nicotianamine transporter that is regulated by iron and expressed in the phloem. Plant J. 39, 415-424. doi: 10.1111/j.1365313X.2004.02146.x

Korshunova, Y. O., Eide, D., Clark, W. G., Guerinot, M. L., and Pakrasi, H. B. (1999). The IRT1 protein from Arabidopsis thaliana is a metal transporter with a broad substrate range. Plant Mol. Biol. 40, 37-44. doi: 10.1023/A:10264386 15520

Larbi, A., Morales, F., Abadía, A., and Abadía, J. (2010). Changes in iron and organic acid concentrations in xylem sap and apoplastic fluid of iron-deficient Beta vulgaris plants in response to iron resupply. J. Plant Physiol. 167, 255-260. doi: 10.1016/j.jplph.2009.09.007

Larbi, A., Morales, F., López-Millán, A.-F., Gogorcena, Y., Abadía, A., Moog, P. R., et al. (2001). Technical advance: reduction of Fe(III)-chelates by mesophyll leaf discs of sugar beet. Multi-component origin and effects of Fe deficiency. Plant Cell Physiol. 42, 94-105. doi: 10.1093/pcp/pce012

Lazlo, J. A. (1990). Mineral contents of soybean seed coats and embryos during development. J. Plant Nutr. 13, 231-248. doi: 10.1080/01904169009364070

López-Millán, A.-F., Ellis, D. R., and Grusak, M. A. (2004). Identification and characterization of several new members of the ZIP family of metal transporters in Medicago truncatula. Plant Mol. Biol. 54, 583-596. doi: 10.1023/B:PLAN.0000038271.96019.aa

López-Millán, A. F., Morales, F., Andaluz, S., Gogorcena, Y., Abadía, A., De las Rivas J., etal. (2000). Responses of sugar beet roots to iron deficiency. Changes in carbon assimilation and oxygen use. Plant Physiol. 124, 885-897. doi: 10.1104/pp.124.2.885

López-Millán, A.-F., Morales, F., Gogorcena, Y., Abadía, A., and Abadía, J. (2009). Metabolic responses in iron deficient tomato plants. J. Plant Physiol. 66, 375-384. doi: 10.1016/j.jplph.2008.06.011 
Lucas, W. J., Groover, A., Lichtenberger, R., Furuta, K., Yadav, S.-R., Helariutta, Y., et al. (2013). The plant vascular system: evolution, development and functions. $J$. Integr. Plant Biol. 55, 294-388. doi: 10.1111/jipb.12041

Majumder, N. D., Rakshit, S. C., and Borthakur, D. N. (1990). Genetic effect on uptake of selected nutrients in some rice (O. sativa L.) varieties in phosphorus deficient soils. Plant Soil 123, 117-120.

Marentes, E., and Grusak, M. A. (1998). Iron transport and storage within the seed coat and embryo of developing seeds of pea (Pisum sativum L.). Seed Sci. Res. 8 , 367-375. doi: 10.1017/S0960258500004293

Marschner, H. (1995). Mineral Nutrition of Higher Plants, 2nd Edn. San Diego, CA: Academic Press Inc.

Marschner, H., Römheld, V., and Ossenberg-Neuhaus, H. (1982). Rapid method for measuring changes in $\mathrm{pH}$ and reducing processes along roots of intact plants. Z. Pflanzenphysiol. 105, 407-416. doi: 10.1016/S0044-328X(82) 80038-X

Masuda, H., Ishimaru, Y., Aung, M. S., Kobayashi, T., Kakei, Y., Takahashi, M., et al. (2012). Iron biofortification in rice by the introduction of multiple genes involved in iron nutrition. Sci. Rep. 2, 543. doi: 10.1038/srep00543

Mukherjee, I., Campbell, N. H., Ash, J. S., and Connolly, E. L. (2006). Expression profiling of the Arabidopsis ferric chelate reductase (FRO) gene family reveals differential regulation by iron and copper. Planta 223, 1178-1190. doi: 10.1007/s00425-005-0165-0

Ramani, S., and Kannan, S. (1987). Manganese absorption and transport in rice. Physiol. Plant. 33, 133-137. doi: 10.1111/j.1399-3054.1975.tb03780.x

Rellán-Álvarez, R., Giner-Martínez-Sierra, J., Orduna, J., Orera, I., RodríguezCastrillón, J. A., García-Alonso, J. I., et al. (2010). Identification of a tri-Iron(III) tri-citrate complex in the xylem sap of iron-deficient tomato resupplied with iron: new insights into plant iron long-distance transport. Plant Cell Physiol. 51, 91-102. doi: 10.1093/pcp/pcp170

Remy, E., Cabrito, T. R., Batista, R. A., Teixeira, M. C., Sá-Correia, I., and Duque, P. (2012). The Pht1;9 and Pht1;8 transporters mediate inorganic phosphate acquisition by the Arabidopsis thaliana root during phosphorus starvation. New Phytol. 195, 356-371. doi: 10.1111/j.1469-8137.2012.04167.x

Robinson, N. J., Procter, C. M., Connolly, E. L., and Guerinot, M. L. (1999). A ferric-chelate reductase for iron uptake from soils. Nature 397, 694-697. doi: $10.1038 / 17800$

Rodríguez-Celma, J., Lin, W.-D., Fu, G.-M., Abadía, J., López-Millán, A.-F., and Schmidt, W. (2013). Mutually exclusive alterations in secondary metabolism are critical for the uptake of insoluble iron compounds by Arabidopsis and Medicago truncatula. Plant Physiol. 162, 1473-1485. doi: 10.1104/pp.113.220426

Römheld, V., and Marschner, H. (1986). Evidence for a specific uptake system for iron phytosiderophores in roots of grasses. Plant Physiol. 80, 175-180. doi: 10.1104/pp.80.1.175

Schagerlof, U., Wilson, G., Hebert, H., Al-Karadaghi, S., and Hagerhall, C. (2006). Transmembrane topology of FRO2, a ferric chelate reductase from Arabidopsis thaliana. Plant Mol. Biol. 62, 215-221. doi: 10.1007/s11103-006-9015-0

Sperotto, A., Vasconcelos, M. W., Grusak, M. A., and Fett, J. P. (2012). Effects of different Fe supplies on mineral partitioning and remobilization during the reproductive development of rice (Oryza sativa L.). Rice 5, 27. doi: 10.1186/19398433-5-27

Stephan, U. W., and Grün, M. (1989). Physiological disorders of the nicotianamineauxotroph tomato mutant chloronerva at different levels of iron nutrition. II. Iron deficiency response and heavy metal metabolism. Biochem. Physiol. Pflanzen 185, 189-200. doi: 10.1016/S0015-3796(89)80080-0

Thomine, S., Lelièvre, F., Debarbieux, E., Schroeder, J. I., and Barbier-Brygo, H. (2003). AtNRAMP3, a multispecific vacuolar metal transporter involved in plant responses to iron deficiency. Plant J. 34, 685-695. doi: 10.1046/j.1365313X.2003.01760.x
Tiffin, L. O. (1966). Iron translocation. I. Plant culture, exudate sampling, ironcitrate analysis. Plant Physiol. 41, 510-514. doi: 10.1104/pp.41.3.510

Tiffin, L. O. (1971). Translocation of nickel in xylem exudates of plants. Plant Physiol. 48, 273-277. doi: 10.1104/pp.48.3.273

Truty, J., Malpe, R., and Linder, M. C. (2001). Iron prevents ferritin turnover in hepatic cells. J. Biol. Chem. 276, 48775-48780. doi: 10.1074/jbc.M105392200

Vasconcelos, M. W., Eckert, H., Arahana, V., Graef, G., Grusak, M. A., and Clemente, T. (2006). Molecular and phenotypic characterization of transgenic soybean expressing the Arabidopsis ferric chelate reductase gene, FRO2. Planta 224, 1116-1128. doi: 10.1007/s00425-006-0293-1

Vert, G., Grotz, N., Dedaldechamp, F., Gaymard, F., Guerinot, M. L., Briat, J.-F., et al. (2002). IRT1, an Arabidopsis transporter essential for iron uptake from the soil and plant growth. Plant Cell 14, 1223-1233. doi: 10.1105/tpc.001388

Walker, E. L., and Waters, B. M. (2011). The role of transition metal homeostasis in plant seed development. Curr. Opin. Plant Biol. 14, 318-324. doi: 10.1016/j.pbi.2011.03.025

Waters, B. M., and Grusak, M. A. (2008). Whole-plant mineral partitioning throughout the life cycle in Arabidopsis thaliana ecotypes Columbia, Landsberg erecta, Cape Verde Islands, and the mutant line ysllysl3. New Phytol. 177, 389-405.

Welch, R. M., and LaRue, T. A. (1990). Physiological characteristics of Fe accumulation in the 'bronze' mutant of Pisum sativum L., cv 'sparkle' E107 (brz brz). Plant Physiol. 93, 723-729. doi: 10.1104/pp.93.2.723

White, P. J., and Broadley, M. R. (2009). Biofortification of crops with seven mineral elements often lacking in human diets - iron, zinc, copper, calcium, magnesium, selenium and iodine. New Phytol. 182, 49-84. doi: 10.1111/j.14698137.2008.02738.x

Yi, Y., and Guerinot, M. L. (1996). Genetic evidence that induction of root Fe3+ chelate reductase activity is necessary for iron uptake under iron deficiency. Plant J. 10, 835-844. doi: 10.1046/j.1365-313X.1996.10050835.x

Zhang, C., Römheld, V., and Marschner, H. (1995). Retranslocation of iron from primary leaves of bean plants grown under iron deficiency. J. Plant Physiol. 146, 268-272. doi: 10.1016/S0176-1617(11)82052-3

Zeng, Y. W., Shen, S. Q., Wang, L. X., Liu, J. F., Pu, X. Y., Du, J., et al. (2005). Correlation of plant morphological and grain quality traits with mineral element contents in Yunnan rice. Rice Sci. 12, 101-106.

Zimmermann, M., Clarke, O., Gulbis, J. M., Keizer, D. W., Jarvis, R. S., Cobbett, C. S., et al. (2009). Metal binding affinities of Arabidopsis zinc and copper transporters: selectivities match the relative, but not the absolute, affinities of their aminoterminal domains. Biochemistry 48, 11640-11654. doi: 10.1021/bi901573b

Conflict of Interest Statement: The authors declare that the research was conducted in the absence of any commercial or financial relationships that could be construed as a potential conflict of interest.

Received: 30 November 2013; paper pending published: 01 January 2014; accepted: 10 March 2014; published online: 03 April 2014.

Citation: Vasconcelos MW, Clemente TE and Grusak MA (2014) Evaluation of constitutive iron reductase (AtFRO2) expression on mineral accumulation and distribution in soybean (Glycine max. L). Front. Plant Sci. 5:112. doi: 10.3389/fpls.2014.00112

This article was submitted to Plant Nutrition, a section of the journal Frontiers in Plant Science.

Copyright (C) 2014 Vasconcelos, Clemente and Grusak. This is an open-access article distributed under the terms of the Creative Commons Attribution License (CC BY). The use, distribution or reproduction in other forums is permitted, provided the original author(s) or licensor are credited and that the original publication in this journal is cited, in accordance with accepted academic practice. No use, distribution or reproduction is permitted which does not comply with these terms. 